\title{
DISTRIBUTION OF POTAMOPYRGUS ANTIPODARUM (GRAY, 1843) IN WATERS OF THE WIGRY NATIONAL PARK (NE POLAND) AND THE EFFEGT OF SELECTED HABITAT FACTORS ON ITS OCGURRENCE
}

\author{
TOMASZ BRZEZIŃSKI, ANDRZEJ KOŁODZIEJCZYK
}

\author{
Department of Hydrobiology, Institute of Zoology, University of Warsaw, Banacha 2, 02-097 Poland \\ (e-mail: kol@hydro.biol.uw.edu.pl)
}

\begin{abstract}
The occurrence of the snail Potamopyrgus antipodarum (Gray) in the waters of the Wigry National Park was studied, and the factors, affecting its distribution and dispersal, were analysed in 1997-1998. P. antipodarum was recorded from 7 out of the 24 examined water bodies of the Park and from the river Kamionka. The snail occurred in bottom deposits, on submerged and emerged macrophytes and in mats of filamentous algae in the lake Wigry, and clearly dominated in its malacofauna. In the remaining lakes, where it was present, it was not abundant. Active dispersal is not sufficient to explain the distribution of $P$. antipodarum in the lake Wigry. Its dispersal is probably a result of passive introduction by animals and humans, and to a lesser extent by water currents. An increased chlorophyll concentration in the pelagial has a positive effect on the occurrence of $P$. antipodarum. In much polluted habitats the vertical distribution and density of the species are limited. Significance of the trophy of water for the occurrence of $P$. antipodarum in the area is still unclear.
\end{abstract}

KEY WORDS: Potamopyrgus antipodarum, eutrophication, pollution, filamentous algae

\section{INTRODUCTION}

Potamopyrgus antipodarum (Gray, 1843) originating from New Zealand, has been spreading in Poland since 1933 (URBAŃSKI 1935). It was found in some water bodies of the Baltic Coast, Pomeranian Lakeland, Wielkopolsko-Kujawska Lowland (JACKIEWICZ 1973), Iławskie Lakeland (WOLNOMIEJSKI \& FURYK 1970), Mazurian Lakeland (KoŁODZIEJCZYK 1984), and also of Upper Silesia (STRZELEC \& SERAFIŃSKI 1996). Due to its considerable fertility and parthenogenic reproduction, $P$. antipodarum can within a short time invade a water body where it has been introduced (STRZELEC \& SERAFIŃSKI 1996), however it later disappears from some lakes, e.g. the Mikołajskie Lake (KOŁODZIEJCZYK 1984). Abundance fluctuations observed in populations of the species are difficult to interpret. It is unknown if biotic factors affect populations of $P$. antipodarum in newly-invaded areas. According to WinTERBOURNe (1970), in New Zealand the abundance of the species does not depend significantly on biotic, but on physical factors of catastrophic character (e.g. floods - HOLOMUZKI \& BIGGS 1999). DORGELO's (1987) studies revealed no differences between populations of $P$. antipodarum inhabiting two lakes of different trophy. The snail may live in strongly polluted waters (STRZELEC \& KRODKIEWSKA 1994).

In the waters of the Wigry National Park, $P$. antipodarum was first found by LEWANDOWSKI (1992) who recorded it from the lake Wigry and classified it as a rare species. In 1993, KOŁODZIEJCZYK (1996) found it in the lake Białe Wigierskie. GRUŻEWSKI (1997) recorded it from the river Kamionka. Preliminary information on the distribution of the species in the waters of the Wigry National Park was presented by BRZEZIŃSKI (1999).

The aim of our study was to assess the frequency and abundance of $P$. antipodarum in the waters of the Wigry National Park, and to estimate the significance of trophy, degree of pollution and presence of mats of filamentous algae for its occurrence. 


\section{STUDY AREA AND METHODS}

The Wigry National Park is located in the mid part of the Czarna Hańcza River basin. The hydrographic system of the Park includes 42 lakes which vary considerably in size, depth, trophy, degree of isolation and vegetation, as well as 6 water-courses. The malacofauna was sampled in 1997 and 1998, at the end of July/beginning of August, from 24 lakes (Table 1) and 5 water-courses of the area. In each water body, depending on its size and diversification, from 1 to 21 sites were selected (Fig. 1). At each site, samples of emerged and submerged macrophytes were taken, of filamentous algae and bottom deposits from a depth of $0.5 \mathrm{~m}$. In some localities, samples of bottom deposits were taken as vertical profiles: from the shoreline (when possible) and depths of 0.5 , $1.0-1.5,2.0-4.0,7.0-10.0$ and $10.0-14.0 \mathrm{~m}$. The bottom deposits were sampled with Ekman-Birge grab of catching area of $225 \mathrm{~cm}^{2}$ (3-5 samples). At each locality, 5 samples were taken of each plant present. One macrophyte sample included: 10 shoots of reed (Phragmites australis Trin. ex Steud.) or Schoenoplectus lacustris L., 10 shoots of Potamogeton perfoliatus L. or $P$. lucens $\mathrm{L}$., a portion of Characeae, a single specimen of Stratiotes aloides L. - swept with a net under water, a portion of filamentous algae (of mixed species composition, Mougeotia sp. being the dominant - studied only in 1998) swept with a container of ca. $400 \mathrm{~cm}^{3}$ volume. In small forest and polyhumus lakes, and in the Wigierski Pond, only qualitative samples were taken. The samples were washed on a benthis sieve of $1 \mathrm{~mm}$ mesh, sorted macroscopically and preserved with methyl alcohol or formalin.

The density of $P$. antipodarum was converted to 1 $\mathrm{m}^{2}$ substratum (bottom, reed shoots, Potamogeton shoots) or $100 \mathrm{~g}$ fresh weight of filamentous algae. The surface area of submerged macrophytes based on their fresh weight was calculated according to HARROD \& HALL (1962), KOWALCZEWSKI (1975) and

Table 1. Selected parameters of investigated lakes in the Wigry National Park (ZDANOWSKI et al. 1992)

\begin{tabular}{|c|c|c|c|c|c|c|}
\hline \multirow{2}{*}{ Lake } & \multirow{2}{*}{ Area [ha] } & \multicolumn{2}{|c|}{ Depth $[\mathrm{m}]$} & \multirow{2}{*}{$\begin{array}{l}\text { Secchi disc } \\
\text { visibility }[\mathrm{m}]\end{array}$} & \multirow{2}{*}{$\begin{array}{c}\mathrm{PO}_{4}-\mathrm{P} \\
{\left[\mathrm{mg} \times \mathrm{dm}^{-3}\right]}\end{array}$} & \multirow{2}{*}{$\begin{array}{c}\text { Plant-covered } \\
\text { area }[\%]\end{array}$} \\
\hline & & maximum & mean & & & \\
\hline Białe Pierciańskie & 6.0 & 24.0 & 6.0 & 4.4 & 0.06 & - \\
\hline Białe Wigierskie & 100.2 & 34.0 & 13.2 & 6.65 & 0.017 & 29.2 \\
\hline Czarne & 6.4 & 10.0 & 10.3 & 1.47 & 0.1 & 64 \\
\hline Czarne Huciańskie & 7.8 & 24.0 & 2.3 & - & - & 21.4 \\
\hline Długie & 80.0 & 14.8 & 6.4 & 3.0 & 0.015 & 23.8 \\
\hline Gałęziste & 3.9 & 14.3 & 5.2 & 3.74 & 0.174 & - \\
\hline Koleśne & 25.5 & 15.0 & 15 & - & - & - \\
\hline Królówek & 9.9 & 4.5 & 2.2 & - & - & 54.5 \\
\hline Leszczewek & 21.0 & 6.5 & 3.6 & 1.1 & - & 31 \\
\hline Muliczne & 25.7 & 11.3 & 4.7 & 3.65 & - & 49 \\
\hline Omółówek & 14.2 & 5.5 & 3.0 & 2.5 & - & 63.3 \\
\hline Okrągłe & 12.2 & 12.8 & 6.7 & 2.6 & 0.004 & 32 \\
\hline Pierty & 228.2 & 38.0 & 10.4 & 1.35 & 0.034 & 25.5 \\
\hline Samle Wielkie & 2.1 & 11.0 & 5.5 & 2.7 & 0.108 & - \\
\hline Staw Wigierski & 30.0 & 11.0 & 11 & - & - & - \\
\hline Suchar I & 0.9 & 4.0 & 5.5 & 1.75 & - & - \\
\hline Suchar II & 2.6 & 9.5 & 2.5 & 1.9 & 0.048 & - \\
\hline Suchar III & 0.33 & 4.0 & 3.6 & 2.0 & - & - \\
\hline Suchar IV & 1.15 & 8.0 & 1.9 & 1.55 & 0.072 & - \\
\hline Suchar V & 0.5 & 5.7 & 3.2 & 2.0 & - & - \\
\hline Suchar Dembowski & 3.3 & 7.5 & 4.3 & 2.9 & 0.021 & - \\
\hline Suchar Wielki & 8.9 & 9.0 & 3.6 & 2.6 & 0.006 & - \\
\hline Wądołek & 1 & 15.0 & 8.6 & 1.5 & 0.24 & - \\
\hline Wigry & 2118.3 & 73.0 & 15.8 & 2.3 & 0.096 & 23.8 \\
\hline
\end{tabular}

- lack of data 


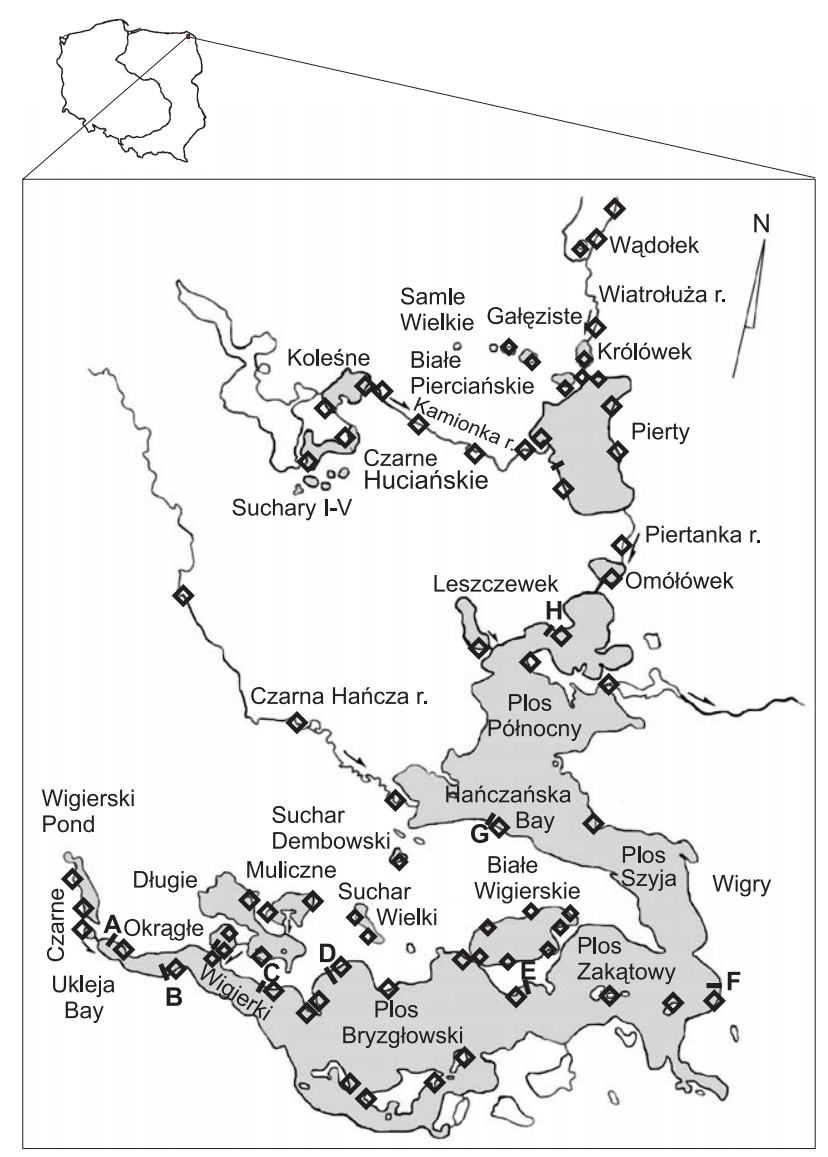

Fig. 1. Study area. Sample sites indicated with squares, water flow indicated with arrows, location of the depth profiles indicated with capital letters

PEREYRA-RAmos (1981). The occurrence of $P$. antipodarum was analysed in detail only on reed, $P$. perfoliatus, in the bottom sediments and on filamentous algae, which were sampled at most sites.

To analyse the dependence between the occurrence of $P$. antipodarum and habitat pollution and trophy, we used CHMIELEWSKI's (1991) data on annual load of organic and inorganic matter, in particular shoreline sections of the lake Wigry, provided by each of 97 micro-basins of the lake, data of BAJKIEWICZ-GRABOWSKA et al. (1992) on annual total phosphorus load in the lake and its bays, and HuTOROWICZ's (1998) data on summer concentration of chlorophyll $a$ in particular parts of the lake. Using in our analysis pollution data from earlier years is justified, since: 1 . because of protection regulations and the lack of funds to reclaim private grounds that are located within the Park, the land usage in the direct drainage area of the lake has not changed (KAMIŃSKI, pers. com.); 2. concentration of biogenic substances and pollution load in the lake have not changed significantly within the last 4 years (HuTOROWICZ 1998, ZDANOWSKI 1998); 3. evaluation of the trophy levels based on zooplankton indices revealed no changes in 1996 compared to 1986 (EJSMONT-KARABIN \& KARABIN 1998, KARABIN \& EJSMONT-KARABIN 1998).

Coefficients of correlation were calculated for the dependence between the density of $P$. antipodarum and the values of trophy and pollution indices. The results were statistically analysed with the programme Statistica v. 95 (Wilcoxon tests for tied pairs, R-Spearman correlations) and Statistics (Kolmogorov-Smirnov test). When necessary the data were transformed as recommended by PARKER (1978) and ŁOMNICKI (1995).

\section{RESULTS}

\section{HORIZONTAL DISTRIBUTION OF P. ANTIPODARUM}

$P$. antipodarum was found in 7 of the examined lakes: Wigry, Białe Wigierskie, Czarne Huciańskie, Koleśne, Okragłe, Pierty and Wigierski Pond, as well as in the river Kamionka. In 6 of them (Czarne Huciańskie, Koleśne, Okrągłe, Pierty and Wigierski Pond), the snail was not recorded prior to 1998 or there were no data on its occurrence (BRZEZIŃSKI 1999). P. antipodarum was not found in small isolated lakes - neither eu- nor mesotrophic (Samle Wielkie, Gałęziste, Białe Pierciańskie), or dystrophic (Suchar I-V, Wądołek, Suchar Wielki, Suchar Dembowski); likewise it was not found in some of the lakes connected with the lake Wigry (Leszczewek, Omółówek, Długie, Muliczne), and in the lake Królówek, though it is connected with Pierty.

In the lake Wigry, $P$. antipodarum was present at 15 out of 21 sites, on all the analysed substrata. Its fre- quency in the lake, calculated for all the substrata, was $63 \%$ in 1997 and $77 \%$ in 1998 (Table 2). In the bottom deposits at the depth of $0.5 \mathrm{~m}$, the mean density of the snail at particular localities varied considerably from $14 \pm 25$ indiv. $\times \mathrm{m}^{-2}$ to $28,500 \pm 25,700$ indiv. $\times \mathrm{m}^{-2}$ (Fig. 2). The highest mean density was observed in sites at Plos Zakatowy (for the topography of the lake see Fig. 1) $\left(10,400\right.$ indiv. $\times \mathrm{m}^{-2}$ in $1997,220-28,500$ indiv. $\times \mathrm{m}^{-2}$ in 1998$)$; the density was clearly lower in Plos Bryzgłowski, Plos Północny and the bay Wigierki (22-800 indiv. $\times \mathrm{m}^{-2}$ in 1997 and 14-2,010 indiv. $\times \mathrm{m}^{-2}$ in 1998). P. antipodarum was not found in the Hańczańska Bay and Plos Szyja. Within the two years of studies, neither the density distribution of the snail within the lake Wigry, nor its mean density in the littoral deposits (2,270 indiv. $\times \mathrm{m}^{-2}$ and 3,570 indiv. $\times \mathrm{m}^{-2}$, respectively) changed statistically significantly (Table $2)$. On reeds the highest mean density of $P$. antipodarum was noted in sites in Plos Bryzgłowski 


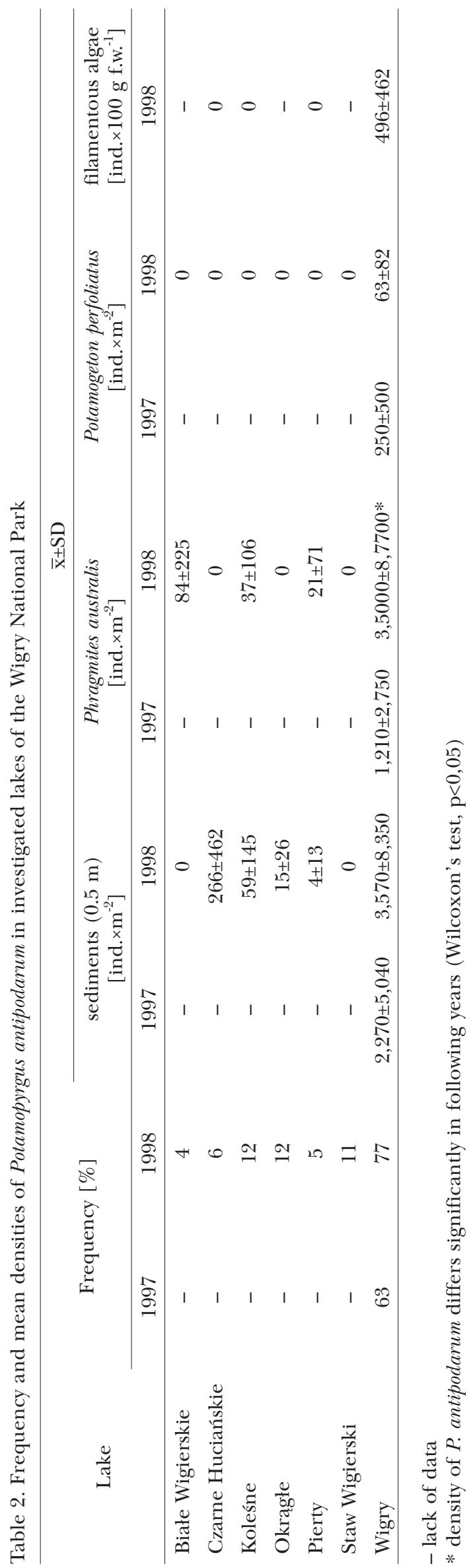

(38-6,520 indiv. $\times \mathrm{m}^{-2}$ in $1997,42-15,200$ indiv. $\times \mathrm{m}^{-2}$ in 1998) and Plos Zakatowy (222 indiv. $\times \mathrm{m}^{-2}$ in 1997 , $11,200-20,400$ indiv. $\times \mathrm{m}^{-2}$ in 1998). The mean density in sites in Plos Północny were clearly lower (2-437 indiv. $\times \mathrm{m}^{-2}$ in 1997, 353 indiv. $\times \mathrm{m}^{-2}$ in 1998). $P$. antipodarum was not found on reeds in Plos Szyja and the bays Hańczańska and Wigierki (Fig. 3). In 1998, compared to 1997, the mean density of the snail on reed in the lake Wigry increased statistically significantly (Table 2), from 1,210 to 35,000 indiv. $\times \mathrm{m}^{-2}$.

On Potamogeton perfoliatus (Fig. 4), the highest mean density of $P$. antipodarum was observed at sites in Plos Bryzgłowski and Plos Zakątowy (39-602 indiv. $\times \mathrm{m}^{-2}$ in 1997, 12-158 indiv. $\times \mathrm{m}^{-2}$ in 1998); it was also high in Plos Północny (8-832 indiv. $\times \mathrm{m}^{-2}$ ) while in the bay Wigierki the mean densities were by an order of magnitude smaller (2-14 indiv. $\times \mathrm{m}^{-2}$ ). Its mean density did not change in 1998 compared to 1997 (Table 2).

$P$. antipodarum was also numerous on other macrophytes sampled in the lake Wigry: Schoenoplectus lacustris, Potamogeton lucens and Stratiotes aloides.

In the mats of filamentous algae (Fig. 5), the highest density of $P$. antipodarum was found in sites of the eastern part of Plos Zakątowy (845-2,040 indiv. $\times 100$ $\left.\mathrm{g}^{-1}\right)$. In the other parts of the lake, the densities were lower and ranged from 19 to 373 indiv. $\times 100 \mathrm{~g}^{-1}$. The species clearly dominated in all the samples of filamentous algae, constituting from $65 \%$ to $99 \%$ molluscs.

In the remaining studied lakes where $P$. antipodarum was found, it was present on some of the substrata sampled, its general frequency being lower (4-12\%) and its density by two or three orders of magnitude lower compared to the lake Wigry (Table 2). In the lake Czarne Huciańskie, the snail occurred in the bottom deposits on one of the two studied localities (Fig. 2), and its total frequency in the samples was only $6 \%$. In the lake Białe Wigierskie, it was present on one of the seven localities examined, on reeds near the neck separating the lake from Wigry (Fig. 3), and its total frequency in the lake was only $4 \%$. In the lake Koleśne, $P$. antipodarum occurred in the bottom deposits (Fig. 2), on reeds (Fig. 3) and on Characeae on both localities, its frequency being $12 \%$. In the lake Okragłe, it was found in the bottom deposits at one of the two sites, close to the outflow to the lake Wigry (Fig. 2), the total frequency in the samples being $12 \%$. In the lake Pierty, it was present in the bottom deposits (Fig. 2) and on reeds (Fig. 3), the frequency being $5 \%$. In the Wigierski Pond, $P$. antipodarum was found to occur on Characeae at one of the two sites (close to the fish stocking station), its frequency being $11 \%$. In none of the lakes, except Wigry, was it noted on Potamogeton perfoliatus (Fig. 4) or mats of filamentous algae (Fig. 5). In the Wigierski Pond and the lake Koleśne, $P$. antipodarum occurred on Characeae, at densities of 0.1 indiv. $\times 100 \mathrm{~g}^{-1}$ and 0.6 indiv. $\times 100 \mathrm{~g}^{-1}$, respectively. 


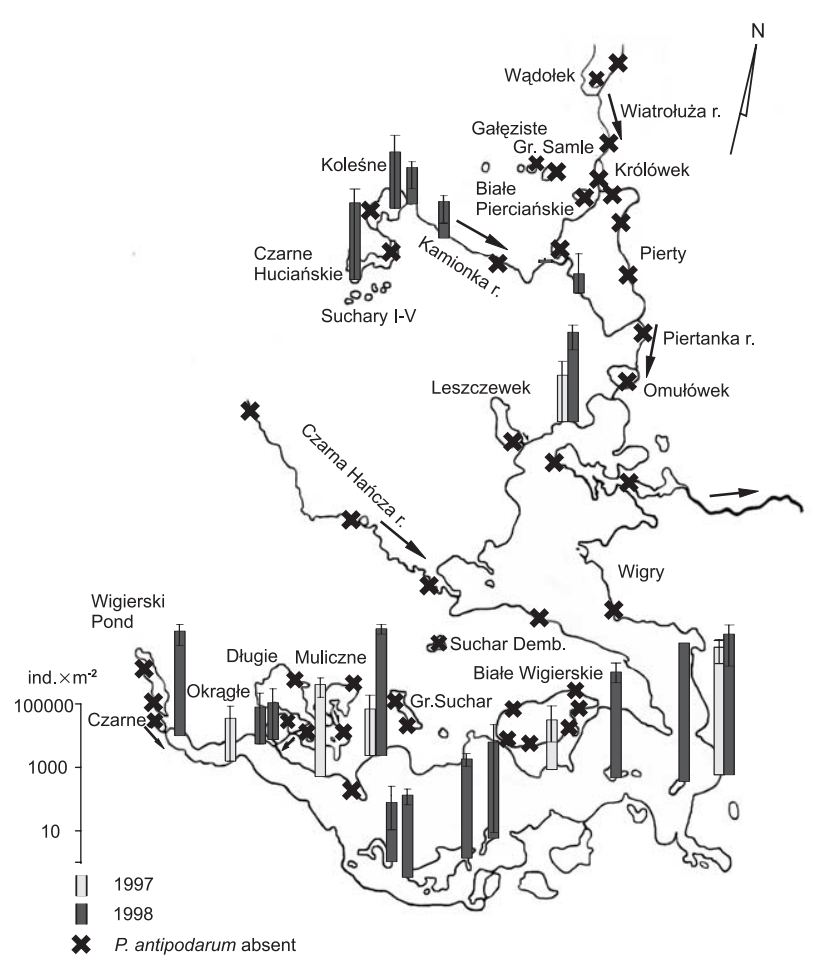

Fig. 2. Density of Potamopyrgus antipodarum in sediments $(0.5 \mathrm{~m})(\overline{\mathrm{x}} \pm \mathrm{SD})$

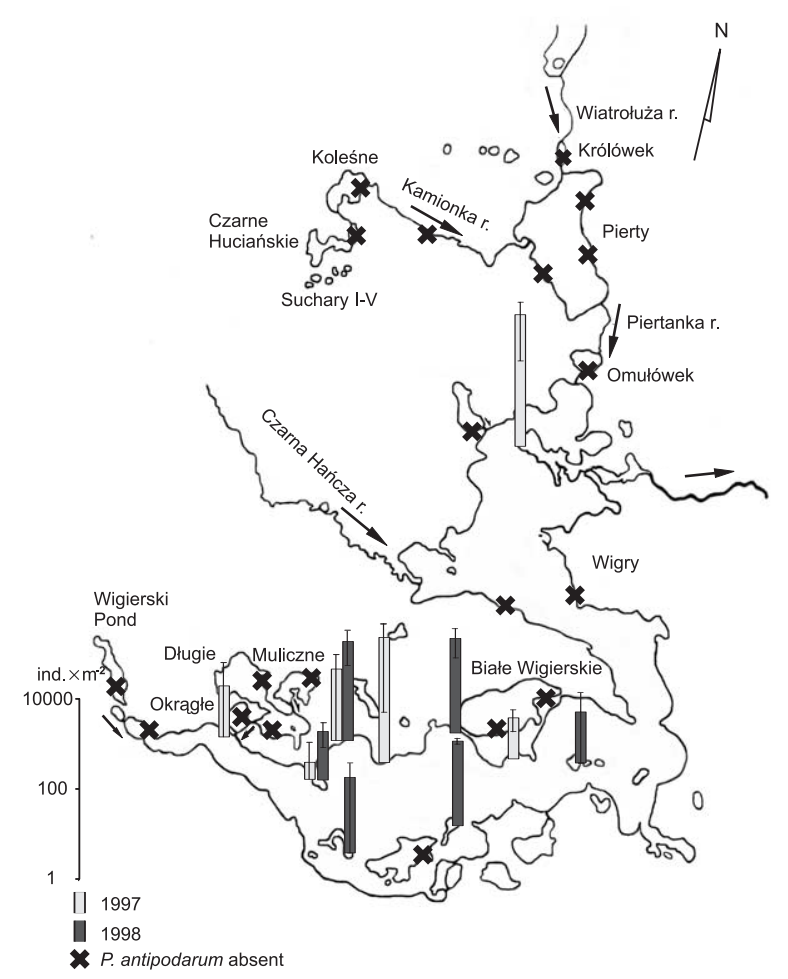

Fig. 4. Density of Potamopyrgus antipodarum on Potamogeton perfoliatus $(\overline{\mathrm{x}} \pm \mathrm{SD})$

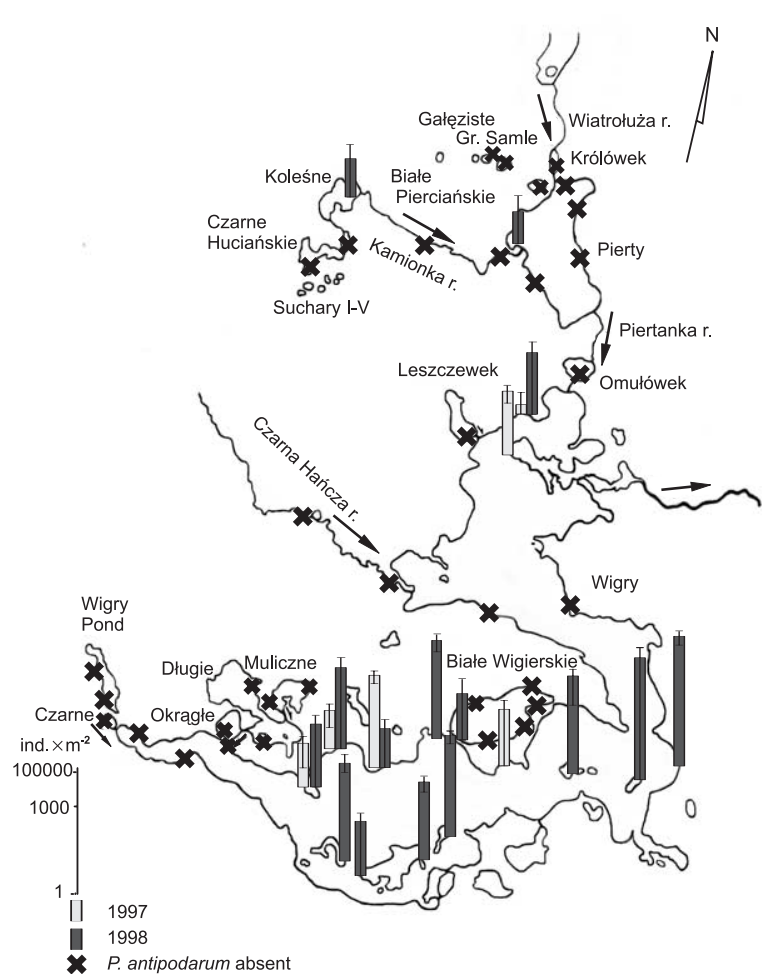

Fig. 3. Density of Potamopyrgus antipodarum on Phragmites australis $(\overline{\mathrm{x}} \pm \mathrm{SD})$

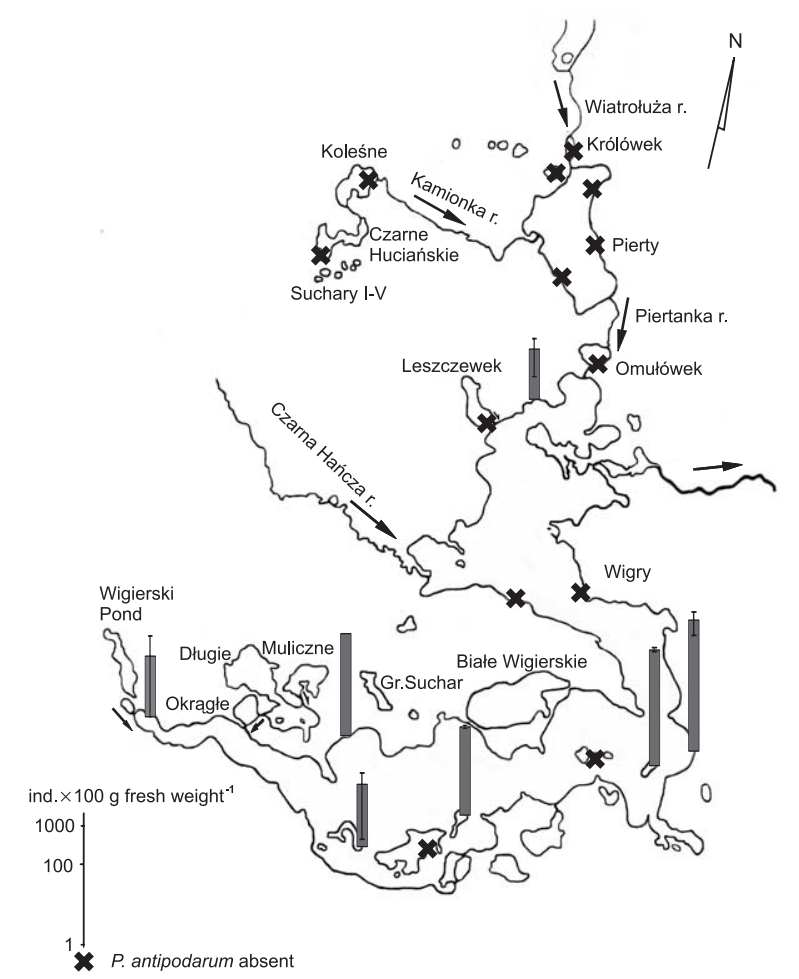

Fig. 5. Density of Potamopyrgus antipodarum in mats of filamentous algae $(\overline{\mathrm{x}} \pm \mathrm{SD})$ 


\section{OCCURRENCE OF P. ANTIPODARUM IN BOTTOM DEPOSITS DEPENDING ON DEPTH}

In the lake Wigry, the maximum depth where $P$. antipodarum was found ranged from $6 \mathrm{~m}$ in Plos Bryzgłowski (1997 and 1998) to $1 \mathrm{~m}$ in 1997 and 0.5 $m$ in 1998 in Plos Północny (Fig. 6). The distribution of density in depth profiles in consecutive years differed statistically significantly; the mean densities of $P$. antipodarum in 1998 were higher than those observed in 1997, showing an increase from 10,400 indiv. $\times \mathrm{m}^{-2}$ to 80,900 indiv. $\times \mathrm{m}^{-2}$ (KolmogorovSmirnov test, $\mathrm{p}<0.001)$, the calculated mean depth where the density was the highest decreased from 1.3 to $0.8 \mathrm{~m}$. The highest densities of $P$. antipodarum were noted in Plos Zakatowy (profiles E, F) and Plos Bryzgłowski (profile D) (Fig. 6). In one of the two profiles in the bay Wigierki (profile B of 1997) and in the Hańczańska Bay (profile G in 1998), $P$. antipodarum was not found. In the lake Okragłe, the snail occurred at shallow depths, $1 \mathrm{~m}$ at the maximum; the calculated mean depth where its density was the highest was $0.8 \mathrm{~m}$. In the lake Pierty, it was found to occur down to the depth of $4 \mathrm{~m}$, and the mean calculated depth, at which the density was the highest, was $2.2 \mathrm{~m}$. In bottom deposit samples from those lakes, the snail was found only sporadically - in 2 out of 14 samples from the lake Okraggłe and 2 out of 15 samples from the lake Pierty, and its vertical distribution was discontinuous.

\section{WATER POLLUTION AND EUTROPHICATION AND THE OCCURRENCE OF P. ANTIPODARUM}

A negative, statistically significant correlation was found between the pollution influx from local microbasins of the lake Wigry and the density reached by $P$. antipodarum on plants (Table 3). The correlation was the most pronounced in case of filamentous algae and Potamogeton perfoliatus, less so in case of reed. No statistically significant correlation was found between the occurrence of $P$. antipodarum in the bottom deposits at the depth of $0.5 \mathrm{~m}$ and the pollution load. There was also a significant, negative correlation between the total phosphorus load and the density of $P$. antipodarum (Table 4 ). The correlation was the most pronounced in case of filamentous algae mats and reed, less so for $P$. perfoliatus and bottom deposits. Likewise, the maximum depth of occurrence of $P$. antipodarum was negatively correlated with phosphorus load (Fig. 7).

A positive, statistically significant correlation was found between the density of $P$. antipodarum in particular sites in the lake Wigry and chlorophyll a concentration in the pelagial (Table 5). The correlation involved all the analysed susbtrata.

However, correlation between the mean density values in particular lakes of the Park and the trophic type of the lake, expressed as categorized values (1 $\alpha$-mesotrophic, 2 - $\beta$-mesotrophic, 3 - eutrophic, $4-$ hypertrophic) was statistically insignificant $(\mathrm{R}=0.495$, $\mathrm{p}<0.06, \mathrm{~N}=16)$.

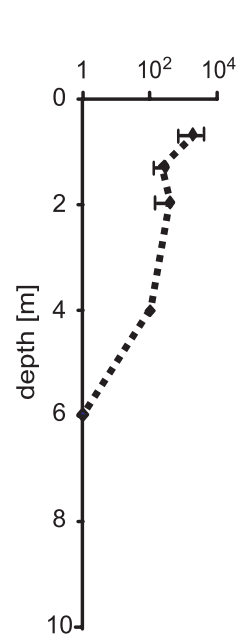

A

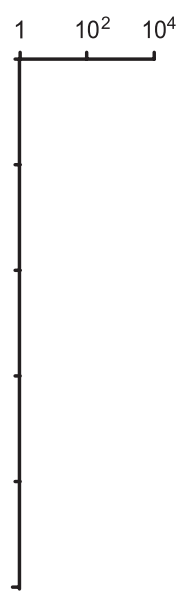

B

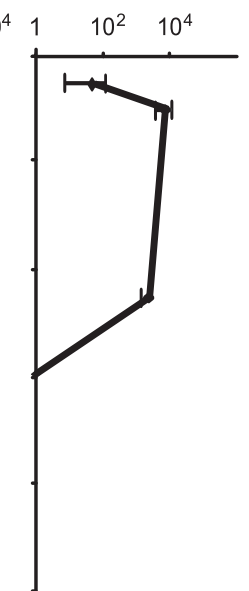

C

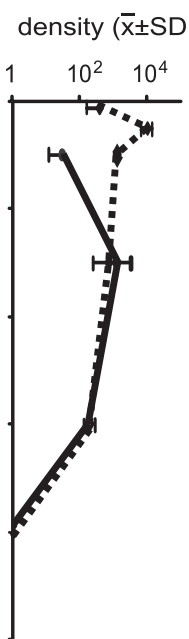

D

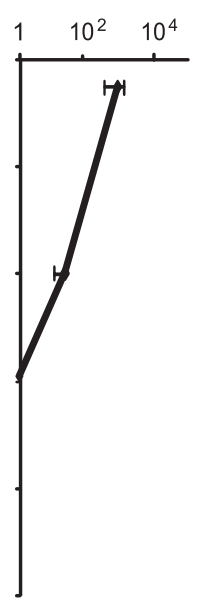

E

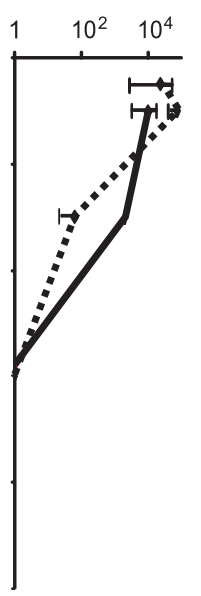

F

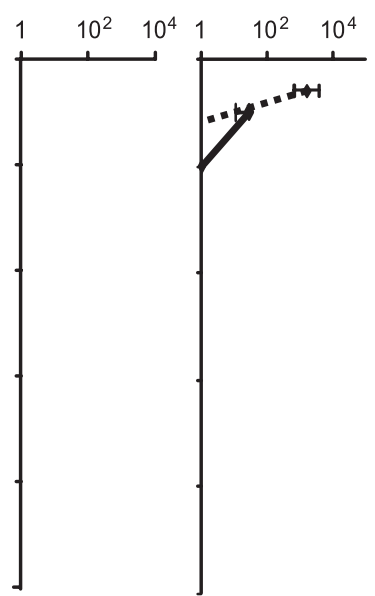

G

H

Fig. 6. Vertical distribution of Potamopyrgus antipodarum in the Wigry Lake. For location of profiles see Fig. 1. In profile A samples were taken in 1998 only, in profiles B, C and E - in 1997 only 
Table 3. Correlation coefficient between densities of Potamopyrgus antipodarum and local pollution load along the shoreline

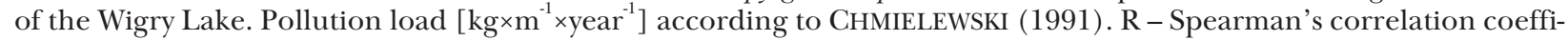
cient, $\mathrm{p}$ - significance, $\mathrm{N}$ - number of samples analysed

\begin{tabular}{lccc}
\hline \multicolumn{1}{c}{ substratum } & $\mathrm{R}$ & $\mathrm{p}$ & $\mathrm{N}$ \\
\hline sediments $(0.5 \mathrm{~m})$ & 0.079 & 0.4 & 92 \\
Phragmites australis & -0.352 & $<0.001$ & 137 \\
Potamogeton perfoliatus & -0.531 & 0.01 & 30 \\
filamentous algae & -0.698 & $<0.001$ & 19 \\
\hline
\end{tabular}

Table 4. Correlation coefficient between densities of Potamopyrgus antipodarum and $\mathrm{P}_{\text {tot }}$ load in the respective parts of the Wigry Lake. $\mathrm{P}_{\text {tot }}$ load [ $\mathrm{g} \mathrm{P}_{\text {tot }} \times \mathrm{m}^{-2} \times$ year $^{-1}$ ] according to BAJKIEWICZ-GRABOWSKA et al. (1992). R - Spearman's correlation coefficient, $\mathrm{p}-$ significance, $\mathrm{N}$ - number of samples analysed

\begin{tabular}{lccr}
\hline \multicolumn{1}{c}{ substratum } & $\mathrm{R}$ & $\mathrm{p}$ & $\mathrm{N}$ \\
\hline sediments $(0.5 \mathrm{~m})$ & -0.325 & 0.01 & 57 \\
Phragmites australis & -0.547 & $<0.001$ & 100 \\
Potamogeton perfoliatus & -0.497 & $<0.008$ & 30 \\
filamentous algae & -0.63 & 0.003 & 19 \\
\hline
\end{tabular}

Table 5. Correlation coefficient between densities of Potamopyrgus antipodarum and chlorophyll $a$ concentration in the respective parts of the Wigry Lake. Chlorophyll $a$ concentration $\left[\mathrm{mg} \times \mathrm{m}^{-3}\right]$ according to HUTOROWICZ (1998). R Spearman's correlation coefficient, $\mathrm{p}$ - significance, $\mathrm{N}$ - number of samples analysed

\begin{tabular}{lccr}
\hline \multicolumn{1}{c}{ substratum } & $\mathrm{R}$ & $\mathrm{p}$ & $\mathrm{N}$ \\
\hline sediments $(0.5 \mathrm{~m})$ & 0.481 & $<0.001$ & 57 \\
Phragmites australis & 0.416 & $<0.001$ & 100 \\
Potamogeton perfoliatus & 0.471 & $<0.001$ & 30 \\
filamentous algae & 0.468 & $<0.001$ & 19 \\
\hline
\end{tabular}

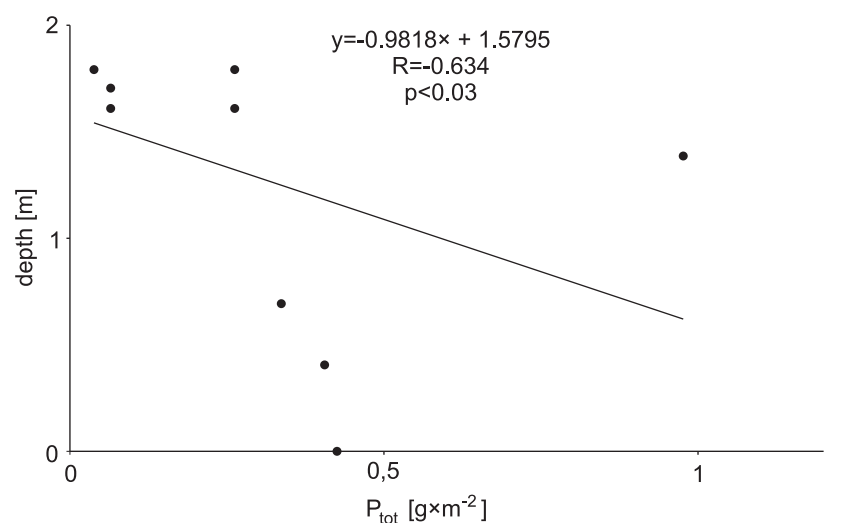

Fig. 7. Maximum vertical range of Potamopyrgus antipodarum as a function of $\mathrm{P}_{\text {tot }}$ load in the respective parts of the Wigry Lake. $P_{\text {tot }}$ load $\left[\mathrm{g} \times \mathrm{m}^{-2} \times\right.$ year $\left.^{-1}\right]$ according BAJKIEWICZ-GRABOWSKA et al. (1992). R - correlation coefficient, $\mathrm{p}$ - significance value

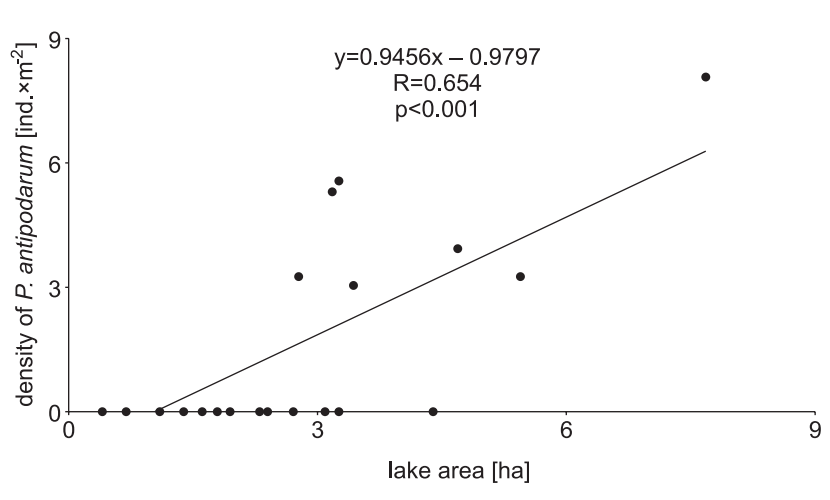

Fig. 8. Density of Potamopyrgus antipodarum in the waters of the Wigry National Park as a function of the lake area. $\mathrm{R}$ - correlation coefficient, $\mathrm{p}$ - significance value 


\section{DISCUSSION}

$P$. antipodarum in the Wigry National Park was found to occur in lakes, which differ considerably among themselves (Table 1). In the studied area, the snail occurs mainly in large and medium-sized water bodies (Fig. 8), irrespective from whether they are isolated or connected by water-courses. Since it was not found in the Czarna Hańcza River drainage area above the lake Wigry, or in other water bodies of the northern part of the Suwalskie Lakeland (KOŁODZIEJCZYK 1989, own unpublished observations), it could not have invaded the lakes actively, along water-courses. It was most probably introduced by humans or animals. BOAG (1986) demonstrated experimentally a possibility of introducing snails by water birds; three routes of bird seasonal migrations cross over Wigry (WOŁK 1979). With this mechanism of dispersal, $P$. antipodarum has the greatest chance of being introduced into large lakes, not only for probability reasons, but also because such lakes are more attractive to waterfowl (JĘDRASZKO-DĄBROWSKA 1992). Large water bodies are also more prone to penetration by humans. Near the lake Wigry and Wigierski Pond, there are fish stocking stations, and thus introduction with fishing equipment or stocking material is also possible. HAYNES et al. (1985) observed that individuals of $P$. antipodarum could pass undamaged through fish alimentary tracts.

The observed considerable differences in the occurrence and abundance of $P$. antipodarum within the lake Wigry may result from different pollution load in particular parts of the lake (Table 3) and different trophy levels (Tables 4, 5). Contrary to the data suggesting a great resistance of $P$. antipodarum to pollution (STRZELEC \& SERAFIŃSKI 1996), the negative correlation between its density at particular localities in the lake Wigry and the local pollution load (Table 3) may indicate a negative effect of pollution on its distribution. $P$. antipodarum occurs in masses in rather unpolluted Plos Bryzgłowski and Plos Zakątowy (Figs 2-5), while it is less numerous in Plos Północny and the bay Wigierki which receive pollutants from the nearby villages: Stary Folwark, Czerwony Folwark, Cimochowizna and Gawrych Ruda. The snail is absent in the strongly eutrophicated Hańczańska Bay receiving, through the Czarna Hańcza river, sewage from Suwałki and Sobolewo. In 1986, P. antipodarum occurred mainly in Plos Północny and there LEWANDOWSKI (1992, per. com.) noted its highest density. At present $P$. antipodarum is rare there and reaches low densities, while the present pollution load there is thrice higher than it was in 1986 (ZDANOWSKI 1998). Likewise, the wide range of maximum depth at which $P$. antipodarum was noted within the lake Wigry (Fig. 6) may result from different habitat conditions, which in turn follow from different pollution load (Fig. 7). In the heavily polluted Plos Północny, the vertical range is small (Fig. 6 - profile $\mathrm{H})$, in relatively little polluted Plos Bryzgłowski, $P$. antipodarum reaches the greatest depths (Fig. 6 - profile D). It seems likely that oxygen deficits near the bottom observed by ZDANOWSKI et al. (1992), as well as other negative aspects of eutrophication associated with anthropogenic transformations of the lake basin, may deteriorate the living conditions of the snail. On the other hand, the positive correlation between the density of $P$. antipodarum and chlorophyll $a$ concentration in the water (Table 5) indicates that a moderately high trophy may favour this snail in consequence of increasing its food resources: biomass of periphyton and planktonic algae. The density of $P$. antipodarum increases with chlorophyll $a$ concentration, however, only up to a certain value. This may result from the fact that increase in chlorophyll content is only one of the many aspects of eutrophication, and the other aspects may have a negative effect on the occurrence of the snail.

The increase in maximum and mean densities of $P$. antipodarum in the bottom deposits in 1997 and 1998 compared to their values of 1986 , when the mean density in the lake Wigry was only $72 \pm 251$ indiv. $\times \mathrm{m}^{-2}$ bottom (LEWANDOWSKI pers. com.), may result both from chlorophyll $a$ concentration, which is at present 4-10 times higher (HuTOROWICZ 1998) and from invasion of more favourable habitats - in 1986, the species was limited to Plos Północny, and was not found in Plos Bryzgłowski or Plos Zakątowy (LEWANDOWSKI 1992), where now it reaches its highest densities.

Besides the local pollution level and trophy, the distribution and abundance of $P$. antipodarum may be significantly affected by the presence of drifting mats of filamentous algae and winds, mainly the prevailing, moderately strong $\left(4 \mathrm{~m} \times \mathrm{s}^{-1}\right)$ westerly and southwesterly winds (BAJKIEWICZ-GRABOWSKA 1992), which push the mats with their animal inhabitants towards the eastern shores of the lake. The high density of the snail in Plos Zakatowy may result from this situation. On such mats $P$. antipodarum could get to some islands on the lake Wigry which are situated outside the shore shallows (island Kamień, islands Brzozowe). It is unknown if the snail prefers staying in the mats of filamentous algae, or is trapped there. According to RYBAK (1996), algal mats do not limit the mobility of copepods and cladocerans; PIECZYŃSKA et al. (1998) demonstrated that the substratum may be attractive to organisms of various taxa, including snails. The range of mean densities of snails reported by these authors for filamentous algal mats in the lake Roś (61-3,500 indiv. $\left.\times 100 \mathrm{~g}^{-1}\right)$ is comparable to the values reached by $P$. antipodarum in the mats of the lake Wigry (18-2,040 indiv. $\times 100 \mathrm{~g}^{-1}$, while the size of young in- 
dividuals of Lymnaea (Stagnicola) sp. which dominate in the lake Roś is similar to that of adult $P$. antipodarum. The presence of mats of filamentous algae increases the surface available for invasion, periphyton developing in algal filaments and the dying fragments of the filaments may constitute a food source; the mats may provide shelter from predators (knowing that a predator - fish - is around, individuals of $P$. antipodarum stay in their shelters longer and feed for shorter periods; LEVRI 1998). Low values of frequency and density of $P$. antipodarum in the remaining lakes of the Wigry National Park may result from the fact that the snail has been present there since recently or that the habitat conditions are not suitable for it. Observations of STRZELEC \& KRODKIEWSKA (1994) from small reservoirs of Upper Silesia indicate that the "conquest" of a water body by $P$. antipodarum takes 2-3 seasons. However, in the lake Białe Wigierskie the snail has been present at least since 1993 (KOŁODZIEJCZYK 1996) but in spite of this its occurrence is limited to the single, and always the same locality near the neck separating the lake from Wigry. Besides, densities it reaches in that site are still very low (1 individual in 5 samples of Characeae in 1993, 7 in 5 reed samples in 1998). It is possible that the five-year period is too short for a conquest of a lake of this size. Though DorgelO's $(1987,1990)$ data do not indicate any density differences between populations of different trophy, it is conceivable that this $\alpha$-mesotrophic, isolated lake does not ensure a proper food basis for the snail; it was demonstrated that the density of $P$. antipodarum was positively correlated with chlorophyll $a$ concentration in the water (Table 5). However, the positive correlation between the trophy and the density of $P$. antipodarum, calculated generally for the lakes of the Wigry National Park, was statistically insignificant. The lack of statitical significance may result from the number of lakes included in the analysis being relatively low (16) and their categorization with respect to trophy which does not reflect their differentiated concentration of biogenic substances. It was, however, necessary to apply such a general classification since there is no single parameter that would unambiguously inform about the trophy level of a lake. The result may be also biased by the fact that $P$. antipodarum is still invading the lakes of the Park, and hence its densities in particular lakes may be far from those potentially possible. Eutrophic lakes, such as Czarne Huciańskie and Koleśne, where the presence of $P$. antipodarum, though discovered in
1998, according to GRUŻEWSKI's (1996) conjectures dates back to at least 1995 , seem to conform to the invasion scenario described by STRZELEC \& KRODKIEWSKA (1994) - the species is still not an absolute dominant, like in the lake Wigry, but seems to play an important role, especially in the malacofauna of bottom deposits. The distribution pattern of $P$. antipodarum in the waters of the Wigry National Park suggests that the species spreads between water bodies in a "lake-hopping" way, irrespective from the lack or presence of connection through water-courses, most probably introduced by animals or humans. Local dispersal within large water bodies may be significantly aided by passive dispersal on drifting algal mats. HERBOLD \& MOYLE (1986) maintain that anthropogenic disturbance of ecosystems creates favourable conditions for invasion of alien species, occupying niches vacated as a result of extinction or decreased abundance of native species. The abundance of snails in eutrophicated lakes is lower than in mesotrophic ones which results, among others, from the limited surface, range and diversity of suitable substrata - macrophytes (PIECZYŃSKA et al. 1998). The changes may be less deleterious to $P$. antipodarum, because of its biology and habitat requirements. The success of invasion of $P$. antipodarum depends probably on the degree of ecosystem disturbance, and neither the lack of any anthropopressure nor its excess favour existence of stable populations of the species. LODGE (1993) pointed to ecological results of invasion of alien species. KRODKIEWSKA et al. (1998) suggest a possibility of dislodging of authochthonous snail species by $P$. antipodarum from water bodies of Upper Silesia. The invasion of $P$. antipodarum requires more detailed studies on its effect on native biocoenoses, if only because of the scale of the phenomenon.

\section{ACKNOWLEDGEMENTS}

We are grateful to the vice-director of the Wigry National park, Dr. MACIEJ KAMIŃSKI for his logistic help during field work, and to Dr. KRZYSZTOF LEWANDOWSKI for making available data on molluscs of the lake Wigry of 1986. Ms. MONIKA SAŁAŃSKA, Ms. AGNIESZKA TWARÓG and Ms. EDYTA WALTERSKA participated in collecting the material; their help is gratefully acknowledged. The study was financed by the grant from the State Committee for Scientific Research, No. 6 P04G 02313.

\section{REFERENCES}

BAJKIEWICZ-GRABOWSKA E. 1992. Charakterystyka fizycznogeograficzna i klimatyczna parku. In: Jeziora Wigierskiego Parku Narodowego. Stan eutrofizacji i kierunki

ochrony. (ZDANOWSKI B., ed.), pp. 1-35, Zakład Narodowy im. Ossolińskich, Kraków. 
BAJKIEWICZ-GRABOWSKA E., HILLBRICHT-ILKOWSKA A., ZDANOWSKI B. 1992. Ocena podatności na degradację, stanu czystości wód i tempa eutrofizacji jezior. In: Jeziora Wigierskiego Parku Narodowego. Stan eutrofizacji i kierunki ochrony. (ZDANOWSKI B., ed.), pp. 163-191, Zakład Narodowy im. Ossolińskich, Kraków.

BOAG D. A. 1986. Dispersal in pond snails: potential role of waterfowl. Can. J. Zool. 64: 904-909.

BRZEZIŃSKI T. 1999. New localities of Potamopyrgus antipodarum (Gray, 1843) in the waters of the Wigry National Park. Folia Malacol. 7: 103-107.

CHMIELEWSKI S. 1991. Charakterystyka ogólna środowiska abiotycznego Wigierskiego Parku Narodowego. In: Wigierski Park Narodowy (KostrowiCKI A. S., ed.), pp. 7-17, LOP, Warszawa.

DORGELO J. 1987. Density fluctuations in populations (1982-1986) and biological observations of Potamopyrgus jenkinsi in two trophically differing lakes. Hydrobiol. Bull. 21: 95-110.

DORGELO J. 1991. Growth, food and respiration in the prosobranch snail Potamopyrgus jenkinsi (E. A. Smith) (Hydrobiidae, Mollusca). Verh. Internat. Verein. Limnol. 24: 2947-2953.

EJSMONT-KARABIN J., KARABIN A. 1998. Zespół stratyfikowanych termicznie jezior Wigierskiego Parku Narodowego - próba waloryzacji ekologicznej przy użyciu wskaźników zooplanktonowych. Conference: Funkcjonowanie i ochrona ekosystemów wodnych na obszarach chronionych Krzywe 1998. Wigry National Park: 6.

GRUŻEWSKI M. 1996. Mięczaki rzeki Kamionki w Wigierskim Parku Narodowym. XII Krajowe Seminarium Malakologiczne Łódź 25-27.IV.1996. Wyd. Uniw. Łódzkiego: 10.

HARROD J. J., HALL R.E. 1962. A method for determinig the surface areas of various aquatic plants. Hydrobiologia 20: $173-178$.

HAYNeS A., TAYlor B. J. R., VARLEY M. E. 1985. The influence of the mobility of Potamopyrgus jenkinsi (E. A. Smith) (Prosobranchia: Hydrobiidae) on its spread. Arch. Hydrobiol. 103: 497-508.

Herbold B., MoYle P. B. 1986. Introduced species and vacant niches. Am. Nat. 128: 751-760.

HolomuZKi J. R., BigGS B. F. 1999. Distribution responses to flow disturbance by a stream dwelling snail. Oikos 87 : $36-47$.

HUTOROWICZ A. 1998. Zbiorowisko fitoplanktonu jako wskaźnik eutrofizacji jeziora Wigry. Conference: Funkcjonowanie i ochrona ekosystemów wodnych na obszarach chronionych Krzywe 11-13.V.1998. Wigierski Park Narodowy: $7-8$.

JACKIEWICZ M. 1973. Nowe stanowiska ślimaka Potamopyrgus jenkinsi (E. A. Smith, 1889) w Polsce i uwagi o jego rozmieszczeniu. Przegl. Zool. 17: 363-366.

JĘDRASZKO-DĄBROWSKA D. 1992. Znaczenie dla ptaków różnych typów zbiorników wodnych w Warszawie jako środowisk lęgowych. In: Problemy ochrony i kształtowanie środowiska przyrodniczego na obszarach zurbanizowanych (BERNADZKI E., ed.), t. 2, pp. 47-57, Wyd. SGGW-AR, Warszawa.

KARABIN A., EjSMONT-KARABIN J. 1998. Jezioro Wigry - wieloletnia sukcesja zespołów Rotifera i Crustacea. Confe- rence: Funkcjonowanie i ochrona ekosystemów wodnych na obszarach chronionych Krzywe 11-13.V.1998. Wigierski Park Narodowy: 28.

KoŁODZIEJCZYK A. 1984. Occurrence of Gastropoda in the lake littoral and their role in the production and transformation of detritus. I. Snails in the littoral of Mikołajskie lake - general characteristics of occurrence. Ekol. Pol. 32: 441-468.

KoŁODZIEJCZYK A. 1989. Malacofauna in isolated and interconnected lakes. Arch. Hydrobiol. 114: 431-441.

KOŁODZIEJCZYK A. 1996. Makrofauna bezkręgowa (ze szczególnym uwzględnieniem Gastropoda) na wybranych makrofitach zanurzonych w litoralu Jeziora Białe Wigierskie. Parki Narodowe i Rezerwaty Przyrody 15: 77-88.

KOWALCZEWSKI A. 1975. Periphyton primary production in the zone of submerged vegetation of Mikołajskie Lake. Ekol. pol. 23: 509-543.

KrodKIEWSKa M., StrZelec M., SERAFIŃSKI W. 1998. Wodożytka nowozelandzka, Potamopyrgus antipodarum (Gray) (Gastropoda, Prosobranchia) niebezpieczny przybysz w malakofaunie Polski. Przegl. Zool. 42: 53-60.

LEVRI E. P. 1998. Perceived predation risk, parasitism, and the foraging behavior of a freshwater snail (Potamopyrgus antipodarum). Can. J. Zool. 76: 1878-1884.

LEWANDOWSKI K. 1992. Występowanie i rozmieszczenie mięczaków, ze szczególnym uwzględnieniem małża Dreissena polymorpha (Pall.) w litoralu kilku jezior Wigierskiego Parku Narodowego. In: Jeziora Wigierskiego Parku Narodowego. Stan eutrofizacji i kierunki ochrony (ZDANOWSKI B., ed.), pp. 145-151, Zakład Narodowy im. Ossolińskich, Kraków.

LODGE D. M. 1993. Biological invasions: lessons for ecology. Trends Ecol. Evol. 8: 133-137.

ŁOMNICKI A. 1995. Wprowadzenie do statystyki dla przyrodników. PWN, Warszawa.

PARKER R. E. 1978. Wprowadzenie do statystyki dla biologów. PWN, Warszawa.

PEREYRA-RAmos E. 1981. The ecological role of Characeae in the lake littoral. Ekol. pol. 29: 167- 209.

PIECZYŃSKA E., KoŁODZIEJCZYK A., RYBAK J. I. 1999. The responses of littoral invertebrates to eutrophication-linked changes in plant communities. Hydrobiologia 391: 9-21.

RYBAK J. I. 1996. The swimming behavior of planktonic crustaceans colonizing algal mats. Hydrobiologia 337: 183-186.

STRZELEC M., KRODKIEWSKA M. 1994. The rapid expansion of Potamopyrgus jenkinsi (E. A. Smith, 1889) in Upper Silesia (Southern Poland) (Gastropoda: Prosobranchia: Hydrobiidae). Malak. Abh. 17: 83-86.

STRZELEC M., SERAFIŃSKI W. 1996. Population ecology of Potamopyrgus antipodarum (Gray, 1843) in a recently colonised area: Upper Silesia (Southern Poland). Malak. Abh. 18: $75-82$.

URBAŃSKI J. 1935. Dwa ciekawe gatunki ślimaków w Wielkopolsce. Wyd. Okr. Kom. Ochr. Przyr. w Poznaniu 5: 108-114.

Winterbourn M. J. 1970. The New Zealand species of Potamopyrgus (Gastropoda: Hydrobiidae). Malacologia 10: 133-149. 
WOLNOMIEJSKI N., FURYK A. 1970. Potamopyrgus jenkinsi Smith $\mathrm{w}$ jeziorach iławskich. In: Prace stacji limnologicznej w Iławie Nr 5, pp. 23-30, Zesz. Nauk. Uniw. M. Kopernika, Toruń.

WOŁK K. 1979. Problemy ornitologiczne jeziora Wigry. In: Jezioro Wigry - kolebka hydrobiologii polskiej (CZECZUGA B., ed.), pp. 163-169, PWN, Warszawa.

ZDANOWSKI B. 1998. Eutrofizacja jezior Wigierskiego Parku Narodowego: zagrożenie i ochrona. Conference: Funkcjonowanie i ochrona ekosystemów wodnych na obsza- rach chronionych Krzywe 11-13.V.1998. Wigierski Park Narodowy: 13.

ZDANOWSKI B., KARPIŃSKI A., PRUSIK S. 1992. Warunki środowiskowe wód jezior Wigierskiego Parku Narodowego. In: Jeziora Wigierskiego Parku Narodowego. Stan eutrofizacji i kierunki ochrony (ZDANOWSKI B., ed.), pp. 35-77, Zakład Narodowy im. Ossolińskich, Kraków.

received: December 6th, 2000

accepted: August 1st, 2001 